\title{
Report on the "International Workshop on Climate and Environmental Evolution in the Mesozoic Greenhouse World and 3rd IGCP 609 Workshop on Cretaceous Sea-Level Change"
}

\author{
5-11 September 2015 Nanjing, China
}

Nanjing University, Nanjing, China was the venue for the International Workshop "Climate and Environmental Evolution in the Mesozoic Greenhouse World" and 3rd IGCP 609 Workshop "Cretaceous Sea-Level Change" which were jointly held during September 5-11, 2015. Forty one participants from 10 countries (Austria, China, Egypt, Japan, Nepal, New Zealand, Pakistan, Russia, Slovak Republic, and USA) participated in the meeting. The workshop on 6-7 September was followed by a 4-day field trip with the title "Cretaceous stratigraphy and sedimentology in southeastern China". The meeting programme, abstract volume and field guidebook can be downloaded from the IGCP 609 website (http://www.univie.ac.at/igcp609/index.html). The workshop was co-sponsored by UNESCO/IUGS IGCP 609 Project, by the State Key Laboratory of Mineral Deposits Research, School of Earth Sciences and Engineering, Nanjing University, and by the 973 Project - Ministry of Science and Technology of the People's Republic of China.

The objective of this workshop was to review the progress and new data on studies of Cretaceous Sea-Level Change, as well as Climate and Environmental Evolution in the Mesozoic Greenhouse World, including the non-marine realm. It comprised five scientific sessions: starting with IGCP Project introductions (IGCP 609, IGCP 608, and IGCP 632) The workshop was chaired by project leaders (IGCP 609) Michael Wagreich (Austria) and Xiumian Hu (China), as well as by Chengshan Wang (China), Florentin J. Maurrasse (USA), Yongdong Wang (China), and Greg Ludvigson (USA) respectively. The results of this meeting are going to be published in a proceedings volume with the working title "IGCP 609 Mesozoic greenhouse palaeoclimate and sea-level changes", as a special issue of the journal "Science China Earth Sciences" (SCES).

The three ongoing IGCP projects 608, 609 and 632 are related in that they deal with climate and environmental changes in the later Mesozoic. While IGCP 609 focuses on causes and consequences of Cretaceous short-term climate and sea-level changes, and, thus, more on the marine realm, IGCP 608 (Cretaceous) and IGCP 632 (Jurassic) focus on the study of non-marine ecosystems and environments. The Nanjing meeting was a joint effort of IGCP Projects 609 and 608 .

\section{The Workshop (September 6-7)}

On the two-day's workshop, 28 participants presented results of their current research on Cretaceous sea-level change, as well as climate and environmental evolution in the Mesozoic greenhouse world. At the beginning of the workshop, Prof. Zhemin Tan, vice President of the Nanjing University, gave a warm address and welcomed the participants, on behalf of the Nanjing University.

The first session of IGCP 608,609 , and 632 project introductions comprised three invited talks of the IGCP project leaders: Michael Wagreich (Austria) introduced IGCP 609, Jingeng Sha (China) presented an introduction to IGCP 632, and Hisao Ando (Japan) reviewed the current status of IGCP 608 "Cretaceous Ecosystems and Their Responses to Paleoenvironmental Changes in Asia and the Western Pacific".

The second session "Cretaceous sea-level change" was opened

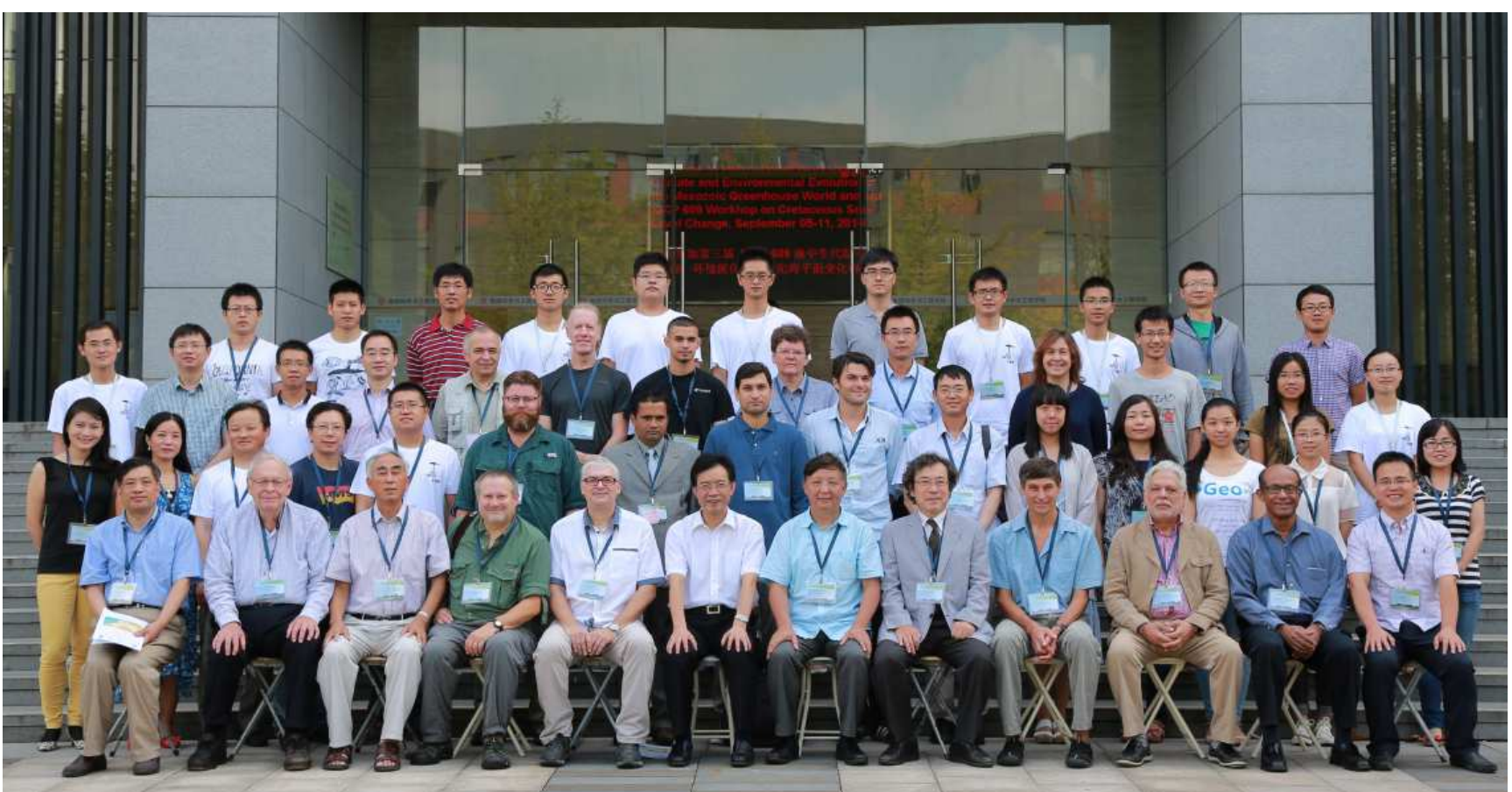

The workshop participants in front of the School of Earth Science and Engineering, Nanjing University 


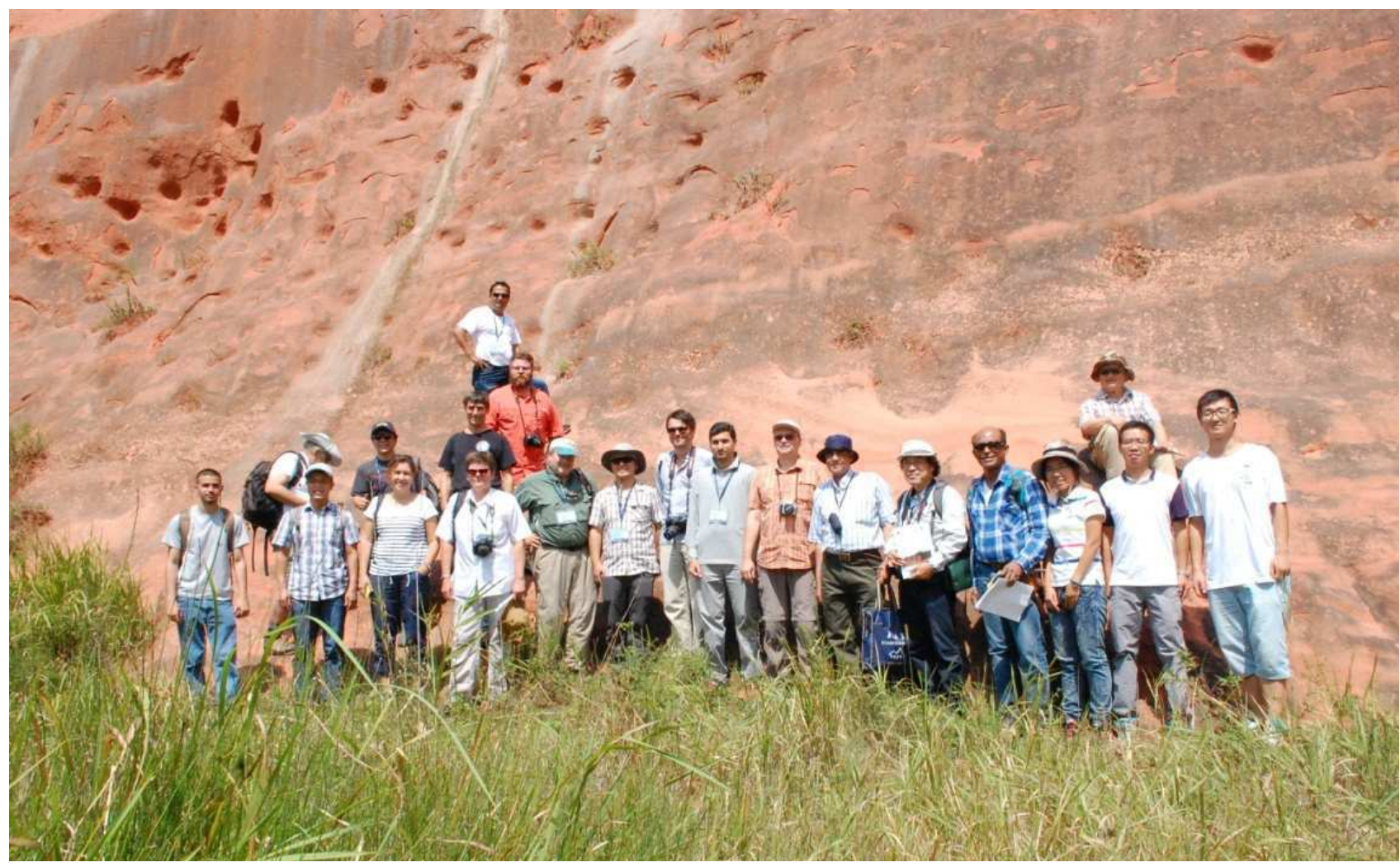

The field trip participants in front of the Upper Cretaceous large-scale aeolian sandstones of the Chishan Formation in Chishan Mountain.

by invited speaker Bilal U. Haq (USA), who explained issues of eustatic and tectonic interactions as exemplified by the Cretaceous stratigraphic record. Elena Iakovishina (Russia) then presented the eustatic events and sedimentation model from the terminal Maastrichtian of the Crimea. Shahid Iqbal (Pakistan/Austria) talked about marine regression and terrestrial onset at the TriassicJurassic boundary: southwestern margin of the Neotethys in the Salt Range, Pakistan. Michael Wagreich presented on integrated stratigraphy and sea-level change around the Santonian-Campanian boundary interval as recorded in the Northern Calcareous Alps of Austria and Germany. Jozef Michalik (Slovakia) gave a talk about Early Cretaceous carbonate platform evolution in the Manín pelagic basin (Central Western Carpathians, Slovakia). Svetlana Zorina (Russia) completed the session with her presentation on Late Cretaceous depositional environments on the Eastern Russian Platform.

Starting the third session, "Mesozoic Climate and Environmental Changes", Brian Huber (USA) introduced in his keynote brief cooling events during greenhouse climates and their possible links to sealevel changes and growth of ice sheets. In the following presentation, Florentin Maurrasse (USA) presented microfacies analysis and paleoenvironments of uppermost Barremian-Lower Aptian deposits of the semi-restricted Organyà Basin, Catalunya, Spain. Erik Wolfgring (Austria) discussed the reconstruction of pelagic paleoenvironments from the Campanian as exemplified by a case study from the Calcareous Alps (Austria), followed by Huimin Liang (China) who gave a talk about methane-derived authigenic carbonates of midCretaceous age in southern Tibet: types of carbonate concretions, carbon sources, and formation processes. Gang Li (China) presented on searching for the non-marine $\mathrm{J} / \mathrm{K}$ boundary in northeastern China, and Jander Socorro (USA) gave a talk about biomarker characterization of the negative carbon isotope shift in segment $\mathrm{C} 2$ of the El Pui section, Organyà Basin, Catalunya, Spain.

The fourth session, "Mesozoic Terrestrial Environments and Geobiological Evolution", was introduced by William W. Hay (USA) who delved into Mesozoic plate tectonics and the evolution of life on land in the context of climate and relief changes. Subsequently, Greg Ludvigson (USA) presented terrestrial paleoclimatic expressions of Aptian-Albian carbon isotope excursions. In the following session, several presentations focused on the terrestrial sediments occurring in Songliao Basin, northern China. Combined with new discoveries of foraminifera, nannofossils, dinoflagellates, and other marine and brackish-water fossils, Dangpeng Xi (China) discussed seawater incursion events in the Songliao Basin. Yuan Gao (China) presented mid-latitude terrestrial stable oxygen and carbon isotopic and clay mineralogical data in the nearly continuous Late Cretaceous age SK1 core drilled in the Songliao Basin. Enxiao Yu (China) presented on two Cretaceous rainy seasons and ENSO signals recorded in the Nenjiang Formation of the Songliao Basin followed by Xianghui Li (China) who gave a talk about geochronology of single zircon $\mathrm{U}-\mathrm{Pb}$ isotope in South China: insights from late Mesozoic terrestrial basins and stratigraphy. Furthermore, Jeffrey Ross (USA) presented on the stable isotope paleohydrology of pedogenic carbonates from the wedge-top depositional zone of the North American Sevier orogenic belt. Finally, several presentations focused on fossil changes and diversity. Yongdong Wang (China) introduced fossil wood diversity and terrestrial paleoclimate variation based on new data from the Mesozoic of China. Mike Pole (New Zealand) presented on floral and climate change at the Cretaceous-Paleogene boundary in New Zealand. Yanhong Pan (China) gave the final talk of this session about taphonomy of bivalves from Jurassic and Lower Cretaceous lakes of NE China. 
In the fifth session, "Mesozoic Abrupt Paleoenvironmental Change and Major Geological Events", several presentations focused on the oceanic anoxic events in the Gongzha section of Tingri, south Tibet, China. Yongxiang Li (China) presented on a high-resolution magnetic and carbon isotope investigation of an expanded Cenomanian-Turonian boundary. Xi Chen (China) then presented the initial results of a study on the Cretaceous OAEs including the identification of the OAE1a and $1 \mathrm{~d}$, and the new findings on the OAE2. Xiaolin Zhang (China) reported on a high-resolution analysis of carbon isotope as well as all four S-isotopic compositions of pyrites. Finally, Juan Li (China) talked about unraveling the Paleocene-Eocene thermal maximum in shallow marine Eastern Tethyan environment: the stratigraphic record in Gamba area (South Tibet).

At the end of the meeting, potential scientific collaboration among the three IGCP projects, future meetings and field trips, and future publications were discussed.

\section{Overview on the field trip}

During the 4-day field trip in the regions of southern Jiangsu, western Zhejiang and northeastern Jiangxi provinces, we visited mainly Cretaceous sections. Major stops and attractions included:
(1) Late Cretaceous continental deposits of the Chishan Formation and Pukou formations (Jiangsu Province); (2) the GSSP section of the Permian-Triassic boundary in Meishan, Zhejiang Province; (3) Cretaceous continental deposits in Jiangxi and Zhejiang provinces; and (4) shallow marine deposits of the Xiangshan Formation (Zhejiang Province).

A major outcome of the meeting is the refinement of the detailed sea-level history and the timing of sea-level cycles for parts of the Cretaceous. The ongoing discussion on causes of short-term sea-level changes during greenhouse times is fostered by further evidence for aquifer- or limno-eustasy, i.e. the potential of continental aquifers and lakes to control significant sea-level fluctuations in the absence of continental ice-sheets.

\section{Juan Li, Xiumian Hu,}

School of Earth Sciences and Engineering,

Nanjing University, Nanjing, China.

Michael Wagreich, Benjamin Sames*,

Department of Geodynamics and Sedimentology,

University of Vienna, Vienna, Austria.

*IGCP609 Secretary.E-mail: benjamin.sames@univie.ac.at 